\title{
RESUMOS DE TESES E DISSERTAÇÕES
}

\section{Gestão Escolar e Gênero: O fenômeno do teto de vidro na educação brasileira}

\author{
Autora: Vanisse Simone Alves Corrêa \\ Nível: Mestrado (PPGE/UFPR) \\ Orientador: Prof. Dr. Ângelo Ricardo de Souza
}

Esta pesquisa tem como objeto de estudo a análise das relações de poder e gênero presentes no acesso à gestão escolar (direção e vice-direção) da Rede Municipal de Ensino de Curitiba e, a partir da análise realizada, constatar a existência do fenômeno do teto de vidro (glass ceiling) bem como suas formas de manifestação neste processo, ou seja, como este fenômeno impacta no resultado das eleições para esses cargos. Para tanto, metodologicamente se utiliza dos dados empíricos referentes à eleição de 2008 para diretores/as e vice-diretores/as das escolas municipais de Curitiba; dos microdados da Prova Brasil 2007 concernentes aos/às diretores/as e de um questionário on-line oferecido aos/ás profissionais da educação municipal de Curitiba. As leituras realizadas para o necessário suporte teórico concentraram-se basicamente em Weber, Bourdieu, Hultin, Foucault e Louro. O estudo conclui que o fenômeno do teto de vidro está presente na educação pública brasileira em geral, e em Curitiba, em especial, e se manifesta de maneira muito contundente quando há homens concorrendo com mulheres no acesso às principais funções da gestão escolar, mesmo quando as mulheres representam a maioria absoluta do professorado, o que leva essas mulheres a uma situação de desvantagem profissional, configurando claramente a existência do teto do vidro ou glass ceiling.

Palavras-chave: Gestão escolar; Eleição para diretores/as; Relações de poder e gênero; Teto de vidro. 


\title{
RESUMOS DE TESES E DISSERTAÇÕES
}

\section{A formação continuada de professores da educação básica pública e a função da universidade: limites e possibilidades da ação da UFPR - Setor Litoral}

\author{
Autora: Paulla Helena Silva de Carvalho \\ Nível: Mestrado (PPGE/UFPR) \\ Orientador: Profa. Dra. Regina Maria Michelotto
}

O presente trabalho apresenta a discussão da formação continuada dos professores da educação básica pública como uma das responsabilidades da universidade. Para tanto, faz-se uma análise do processo de formação de docentes, retomando as intencionalidades de cada momento histórico, assim como uma discussão sobre as responsabilidades da universidade ao longo dos anos. Como foco do estudo analisa-se a relação universidade-escola básica, por meio da formação de professores, para isso foi pesquisada a proposta da UFPR Setor Litoral, a qual expressa em seus objetivos a defesa desta articulação, além de se propor a realizar a formação continuada dos professores da rede pública dos sete municípios do litoral do Paraná. Mais do que uma análise superficial, a pesquisa tenta analisar o discurso exposto nos documentos oficiais do referido setor, nas publicações jornalísticas e na fala dos professores da UFPR, dos municípios litorâneos e dos alunos da Universidade. Em contrapartida, elementos da prática são descritos, pesquisados e discutidos a fim de contrapor a relação teoria e prática, para além de relações lineares. Portanto, a presente pesquisa estuda os limites e possibilidades do Setor UFPR Litoral no que diz respeito ao teor de suas formações continuadas com os professores da rede municipal de ensino de Guaratuba e Pontal do Paraná.

Palavras-chave: Universidade-escola básica. Formação continuada de professores. Responsabilidades da universidade. Relação teoria-prática. 


\section{RESUMOS DE TESES E DISSERTAÇÕES}

\section{Relações raciais, discurso e literatura infanto-juvenil \\ Autora: Débora Cristina de Araujo Nível: Mestrado (PPGE/UFPR) Orientador: Prof. Dr. Paulo Vinícius Baptista Silva}

A presente pesquisa teve como objeto de análise os discursos sobre os grupos raciais brancos e negros, produzidos a partir de leituras de obras infanto-juvenis em salas de aula. A partir dessa perspectiva foi constituído o problema de pesquisa: os discursos da literatura infantojuvenil e sua interpretação, em contexto escolar, apresentam estratégias ideológicas relativas à dominação racial? A metodologia utilizada foi a Hermenêutica da Profundidade (HP), com a proposta de investigar se a produção, veiculação e recepção/interpretação de obras literárias infanto-juvenis apresentavam discursos que atuavam no sentido de produzir/reproduzir hierarquias raciais. A análise de contexto consistiu em análise de bibliografia sobre literatura infanto-juvenil e, em específico, de estudos sobre ideologia e relações raciais relacionados a este gênero literário; análise de documentos relativos ao Programa Nacional Biblioteca na Escola; análise de estudos sobre relações raciais na escola. Para análise formal foi realizado estudo exploratório em uma escola e estudo de campo em outra, que consistiu em presenciar, gravar e transcrever oito aulas de leitura. Foram observadas várias estratégias ideológicas na interpretação das mensagens dos livros, em especial a diferenciação, que se relacionou, neste estudo, ao cânone estabelecido por meio de um modelo eurocêntrico de currículo e literatura infanto-juvenil, conferindo às aulas analisadas nesta pesquisa uma característica de artificialidade, por serem direcionadas única e exclusivamente a obras que tematizam a cultura africana. Outra estratégia recorrente foi a estigmatização, responsável por reforçar préconcepções e estereótipos a respeito da história e cultura afro-brasileira e africana. No que se refere à branquidade (enquanto categoria de análise das relações raciais) resultados ambíguos e divergentes foram encontrados: em alguns momentos, a postura da professora atuou no sentido de reforçar estereótipos ora por meio do silêncio e omissão diante de práticas discriminatórias, ora através de conceituações restritivas e estigmatizantes sobre a população africana; e, em outros, avanços foram verificados por relacionarem-se a alterações na atuação pedagógica de professoras brancas que, diante do compromisso em atender às expectativas desta pesquisa, desenvolveram leituras e posteriores debates que operaram de forma a promover rupturas de um modelo depreciativo de representação da cultura africana. Este resultado, em específico, representou um diferencial em comparação com resultados de outras pesquisas sobre o mesmo tema, as quais identificaram que a branquidade como norma agiu de forma latente no fortalecimento do racismo no espaço escolar. Em síntese, os resultados observados através da interpretação das formas simbólicas apontam que a ideologia se fez presente nos diversos estágios de produção, difusão e, sobretudo, recepção de obras literárias infanto-juvenis.

Palavras-chave: Literatura infanto-juvenil; Relações raciais; Ideologia; Discurso; Hermenêutica da Profundidade. 